Jurnal Kesehatan Masyarakat
http://journal.unnes.ac.id/nju/index.php/kemas

\title{
USATE OF FILTER TUBE TO REDUCE Pb, TURBIDITY AND INCREASE $p H$ OF RAIN WATER FLOWING THROUGH ZINC ROOFTOP HOUSE
}

\author{
Khayan $^{1 \bowtie}$, Husodo $^{2}$, Astuti $^{2}$, Sudarmadji ${ }^{2}$, Sugandawaty ${ }^{2}$ \\ ${ }^{1}$ Poltekkes Kemenkes Pontianak, Kalimantan Barat, Indonesia \\ ${ }^{2}$ Fakultas Kedoteran UGM, Yogyakarta, Indonesia
}

\begin{tabular}{l} 
Info Artikel \\
\hline Article History: \\
Submitted March 2016 \\
Accepted July 2017 \\
Published July 2017 \\
\hline Keywords: \\
Lead (Pb); Turbidity; pH; \\
Filter Tube \\
\hline DOI \\
http://dx.doi.org/10.15294/ \\
kemas.v13i1.9077
\end{tabular}

\section{Introduction}

The target of national healthy water is to increase proportion between house and qualified drinking water source, for both urban and rural region. Nationally, refer to Ministry of Health regulation number 492/2010 about Drinking Water Quality Standard mentions that community who has access to improved drinking water source (protected) is $66.8 \%$ while unimproved is $33.2 \%$. As for West Kalimantan Province, community accsess to improved drinking water source is nearly as many as National proportion with $67.8 \%$. According to Basic Health Research (2013), West Kalimantan communities who have access to improved drinking water source mostly obtain from rain water reservoir $(45.3 \%)$ and this is larger from national proportion which is $2.9 \%$ and other province, like Papua 20\%, Riau 19.3\% and West Papua 15,7\% (Kemenkes, 2014). West Kalimantan community utilize drinking water source from rain water reservoir which the largest is in Kubu Raya District with 90\% proportion and Pontianak City with $78.07 \%$ (Dinkes Kubu Raya, 2014)

High usage of rain water as drinking water source and low usage of other sources like tap water and drilled water is due to rain water on Pontianak is quantitatively abundant and relatively sufficient to health standard requirements. The quality of rain water is physically, chemically and microbiologically sufficient to the standard requirement compare with surface water source and ground water

\footnotetext{
Correspondece Address:

Kampus C Mulyorejo, Surabaya 60115

Email : msrisumarmi@gmail.com
} 
source (Soemirat, 2011). Meanwhile, the service of Pontianak City and Kubu Raya District Water Department, particularly on dry season is in restricted quantity and quality and moreoften contains high salt.

The large practise of rain water usage is supported by West Kalimantan region condition, which has tropical climate, high humidity and rainfall. Observation result on all districts and cities in West kalimantan Province is average rainy days and rainfall per month are quite high, particularly in Pontianak, it reaching 29 days/month with average rainfall $383,04 \mathrm{~mm} / \mathrm{month}$. Highest rainfall is on December with $445,4 \mathrm{~mm} / \mathrm{month}$ and lowest is on June with $128,1 \mathrm{~mm} /$ month (Meteorology Climatology and Geophysics Council, Supadio Pontianak Station, 2014)

Before it is contained in the reservoir, the rain water flowing through zinc rooftop. It is estimated that $90 \%$ of the community use zinc rooftop (West Kalimantan Health Institution). During the manufacturing of zinc rooftop plate, lead is added or layered. The function is to bond the zinc layer with ferous layer and to prevent or reduce the corrotion on the product (Fardiaz, 2012; Palar, 2008). Since rain water is corrosive for containing agresive $\mathrm{CO} 2$ and low $\mathrm{pH}$, around 5.40, it will generate corrotion on the zinc rooftop. Thus, there is possibility that the lead lamitated on the product is dissolved in the rain water and increase $\mathrm{Pb}$ contained in the rain water reservoir.

$\mathrm{Pb}$ contained in rain water, beside coming form the zinc rooftop is worsed by lead exposure from the environtment, such as industrial activity, otomotive emition, agricultural land burning (peat), coal burning and other dust particle (Sastrawijaya, 2000; Sudarmadji, 2014). Then the lead particles is reacted with rain water, cristallized and dissolved (Palar, 2012; Fardiaz, 2012), flows into rain water reservoir and used for community drinking water source. Beside the $\mathrm{Pb}$ exposure, rain water has low $\mathrm{pH}$, between $4.5-<6$ and high turbidity, particularly after few days without raining and direct reservoired from the rain fall.

$\mathrm{Pb}$ exposure on rain water affect community's health, which is enzime disorder, anemia, mental disorder, declined intelegence (IQ) and hyperactivity on children, low birth weight and premature and hypertension on adult (Soemirat, 2011). Inside the body, $\mathrm{Pb}$ is cumulative in the bones and within long term, around 25 years, will ignite chronical poisoned (Kemenkes, 2001).

To reduce $\mathrm{Pb}$ pollutan in the water, some processes is applied, as surface water process by absorbtion with activated carbon and zeolite and filtration using filter tube sand (Adha, 2015). Beside to reduce heavy metals (include $\mathrm{Pb}$ ), the processes could incrase $\mathrm{pH}$ value and reduce turbidity on clean water. For rain water process, nowadays, has not been applied commonly nor properly.

All above are the consideration for researcher to study effectivity of shell sand and activated carbon absorbtion in filter tube to decrease $\mathrm{Pb}$ and turbidity and increase $\mathrm{pH}$ on rain water and the relation with community's health in Pontianak.

\section{Method}

This research will be done with experimental method to evaluate the effectivity of rain water filtration with sand and activated carbon absorbtion in filter tube to decrease $\mathrm{Pb}$ contained by rain water in the reservoir. The experimental design is pre and pose design with control and observational design cross sectional.

The research is conducted in Pontianak with two target regions which are urban and rural one. For urban region is represented by Subdistrict Pontianak Utara Region with two locations which are Siantan Hulu and Siantan Tengah; while for rural region is represented by Subdistrict Sungai Raya with two locations which are Sungai Durian and Limbung.

The population is community and the drinking water source from rain water is from houses flowing rain water through zinc rooftop and directly reservoired. Contains of the rain water measured are $\mathrm{Pb}$ (lead) by using atom absorbting spectrophotometric (AAS), $\mathrm{pH}$ and puridity by using $\mathrm{pH}$ meter and turbidity meter. The community are residents using rain water as drinking water source on urban and rural region. Urban community choosen as samples are Siantan Hulu and Siantan Tengah, while rural community choosen as samples are Sungai Durien and Limbung. Basicly urban region beside the community consume rain 
water flowing through zinc rooftop also being exposed by the pollution from vehicles and factories while the rural region is exposed by pollution from high land burning. The data obtained will be analyzed descriptively based on drinking water quality standard from Ministry of Health and WHO. Also it will be analyzed statisticly with computer program.

\section{Result and Discussion}

Examination result is as descripted on table 1 . It can be known that $\mathrm{Pb}$ contained by rain water flowing through zinc rooftop before process, the highest is from Siantan Tengah, Sub District North Pontianak with average $0.222 \mathrm{mg} / \mathrm{l}(222 \mu \mathrm{g} / \mathrm{l})$ and the lowest is from Limbung, Sub District Sungai Raya with average $0,0446 \mathrm{mg} / \mathrm{l}(44,6 \mu \mathrm{g} / \mathrm{l})$, meanwhile average $\mathrm{Pb}$ contained by rain water flowing through zinc rooftop before process is $0,1317 \mathrm{mg} / \mathrm{l}(131,7$ $\mu \mathrm{g} / \mathrm{l})$ which is above the NAB mentioned ing Ministry of Health regulation number 492 issued in 2010, about The Qualification of Drinking Water and WHO standard (2011) about Guidelines for Drinking Water Quality with value $0.01 \mathrm{mg} / \mathrm{l}(10 \mu \mathrm{g} / \mathrm{l})$. After the process by shell sand filtration technique and coconut shell-made of activated carbon in filter tube, the result has met qualification of drinking water with $0,69 \mu \mathrm{g} / \mathrm{l}$. The effectivity of the filter tube is $99.47 \%$.

From Table 2 can be seen that average rain water turbidity flowing on zinc rooftop before process, the highest is from Siantan Hulu with $22.26 \mathrm{NTU}$ and after process become 9.84 NTU. While average turbidity flowing on zinc rooftop of 40 houses is $20.0 \mathrm{NTU}$ and after process, it decrased to $5.67 \mathrm{NTU}$. The turbidity level after rain water process through filter tube has sufficient to drinking water standard which is 5 NTU. The effectivity of turbidity decrease after the process using shell sand filtration and activated carbon absorbtion in filter tube is $72 \%$.

From Examination report as descripted on table 3 can be found out that rain water $\mathrm{pH}$ flowing through zinc rooftop before process, the lowest is from houses on region of Siantan Hulu with average $\mathrm{pH} 4.62$ and after process has highest increase become $\mathrm{pH}$ 7.01. While average $\mathrm{pH}$ of rain water flowing through zinc

Table 1. Average Pb Contained by Rain Water Before and After Processed

\begin{tabular}{lllll}
\hline District & Administration & $\begin{array}{l}\text { Before Process } \\
(\mu \mathrm{g} / \mathrm{l})\end{array}$ & $\begin{array}{l}\text { After Process } \\
(\mu \mathrm{g} / \mathrm{l})\end{array}$ & $\begin{array}{l}\text { Drinking Water } \\
\text { Qualification }\end{array}$ \\
\hline Pontianak & Siantan Hulu & 201,3 & 0,75 & \\
& Siantan Tengah & 222,0 & 0,77 & $0,01 \mathrm{mg} / \mathrm{l}$ \\
\hline Kubu Raya & Village Limbung & 44,6 & 0,75 & $(10 \mu \mathrm{g} / \mathrm{l})$ \\
& Village Kuala Dua & 58,9 & 0,47 & \\
\hline Average & & 131,7 & 0,69 & \\
\hline
\end{tabular}

( Ministry of Health Regulation No.492/Menkes/Per/IV/2010, Regarding The Qualification of Drinking Water)

Table 2. Average Turbidity of Rain Water Before and After Process

\begin{tabular}{cllll}
\hline District & Administration & $\begin{array}{l}\text { X Before } \\
\text { Process } \\
\text { (NTU) }\end{array}$ & $\begin{array}{l}\text { X After Process } \\
\text { (NTU) }\end{array}$ & $\begin{array}{l}\text { Drinking Water } \\
\text { Qualification }\end{array}$ \\
\hline Pontianak & Siantan Hulu & 22,261 & 9,839 & \\
& Siantan Tengah & 21,572 & 7,872 & \multirow{2}{*}{ 5 NTU } \\
\cline { 1 - 3 } Kubu Raya & Village Limbung & 17,675 & 2,114 & \\
& Village Kuala Dua & 18,502 & 2,831 & \\
\hline Average & & 20,00 & 5,67 & \\
\hline
\end{tabular}

( Ministry of Health Regulation No.492/Menkes/Per/IV/2010, Regarding The Qualification of Drinking Water) 
Table 3. $\mathrm{pH}$ of Rain Water Before and After Process

\begin{tabular}{cllll}
\hline District & Administration & $\begin{array}{l}\text { pH Before } \\
\text { Process } \\
\text { (NTU) }\end{array}$ & $\begin{array}{l}\text { pH After } \\
\text { Process } \\
\text { (NTU) }\end{array}$ & $\begin{array}{l}\text { Drinking Water } \\
\text { Qualification }\end{array}$ \\
\hline Pontianak & Siantan Hulu & 4,626 & 7,001 & \\
& Siantan Tengah & 4,937 & 6,981 & \multirow{2}{*}{$6,5-8,5$} \\
\cline { 1 - 3 } Kubu Raya & Village Limbung & 5,357 & 6,791 & \\
& Village Kuala Dua & 5,721 & 7,014 & \\
\hline Average & & 5,16 & 6,95 & \\
\hline
\end{tabular}

( Ministry of Health Regulation No.492/Menkes/Per/IV/2010, Regarding The Qualification of Drinking Water)

Table 4. Difference of $\mathrm{Pb}$ Contained in Rain Water Before and After Process

\begin{tabular}{|c|c|c|c|c|}
\hline & $\mathrm{N}$ & $\begin{array}{l}\text { Median } \\
\text { (Minimum-Maximum) }\end{array}$ & Average \pm s.b & $\mathrm{P}$ \\
\hline $\begin{array}{l}\text { Pb Before } \\
\text { Process }\end{array}$ & 40 & $\begin{array}{l}0.1018 \\
(0,0032-0,3630)\end{array}$ & $0.131705 \pm 0.1046669$ & \multirow{2}{*}{0,001} \\
\hline $\mathrm{Pb}$ After Process & 40 & $\begin{array}{l}0.0001 \\
(0,0001-0,0030)\end{array}$ & $0,00071 \pm 0,0001434$ & \\
\hline
\end{tabular}

rooftop before process from 40 houses with average $\mathrm{pH} 5.16$ and after process increase to $\mathrm{pH} 6.95$.

From table 4 above, it can be seen that $\mathrm{Pb}$ contained in rain water flowing through zinc rooftop before process by filtration system with shell sand and activated carbon absorbtion in filter tube, $\max \mathrm{Pb}$ value is $363 \mu \mathrm{g} / \mathrm{l}$ and $\min$ $3,2 \mu \mathrm{g} / \mathrm{l}$ and average $131,7 \mu \mathrm{g} / \mathrm{l}$. While after process, the highest value become $0.30 \mu \mathrm{g} / \mathrm{l}$ and the lowest $0,01 \mu \mathrm{g} / \mathrm{l}$, the average is $0,69 \mu \mathrm{g} / \mathrm{l}$. From statistic test result indicates significant difference of rain water $\mathrm{Pb}$ between before and after filtration process with sand shell and activated carbon absorbtion, with $p$ value 0,000 .

Based on Ministry of Health Regulation Number 492/2010, regarding The Qualification of Drinking Water, can be found out that $\mathrm{Pb}$ containment should be $0.01 \mathrm{mg} / \mathrm{l}(10 \mu \mathrm{g} / \mathrm{l})$. From examination result of $\mathrm{Pb}$ contained in rain water flowing through zinc rooftop in Pontianak and Kubu Raya district before process the average value is $131.7 \mu \mathrm{g} / \mathrm{l}$ while lowest value is $3,2 \mu \mathrm{g} / \mathrm{l}$ and highest value is $363 \mu \mathrm{g} / \mathrm{l}$. This indicate that rain water quality directly reservoired from zinc rooftop is not suffition to qualification of drink water

The $\mathrm{Pb}$ contained in rain water in Pontianak and District Kubu Raya is different than the research conducted in Africa, Asia and District Malang East Java. The research by Gakungu (2013) in Embakasi, Nairobi, Africa on rain water flowing through zinc, clay and cement rooftop did not find $\mathrm{Pb}$ containment. As well as the research by Mayouf (2012) on Pb contained by rain water flowing through rooftop and reservoired in tank or shelter in Misurata City, Libya, found that the containment still below detection limit.

The $\mathrm{Pb}$ contained in rain water corroborating evidence that generally rain water has relatively good quality (clean) as drinking water source either physically, chemically and microbiologically. Yet it tends to be polluted while in the atmosphere until falls down to ground surface. The pollution in the atmosphere could be caused by dust particle, microorganism and air components such as Nox, Cox and Sox. The pollutant could be generated by automotive emition and industry (Soemirat, 2012). It can also come from rooftop materials as the surface flown through.

As on this research, average $\mathrm{Pb}$ contained in rain water in Pontianak is higher than District Kubu Raya on sub urban and rural area, which is $211.65 \mu \mathrm{g} / \mathrm{l}$ dan $51,75 \mu \mathrm{g} / \mathrm{l}$. The research in Yogyakarta by Sudarmadji (2014) found out that some elements of phisical, 
chemical and biological parameters are quite high, like dust, $\mathrm{CO}$ and heavy metal like $\mathrm{Pb}, \mathrm{Cu}$ and $\mathrm{Zn}$. The pollutants come from automotive emition (transportation) and industry located on urban area.

Research result indicate that some pollution parameters contained in rain water tend to be higher in urban region compare to suburban (village), as example the test of physics and chemical condition of Malioboro air found out that the lead $(\mathrm{Pb})$ level is $68,24 \mu \mathrm{g} /$ $\mathrm{m}^{3}$ which is higher than Kridosono with 46,97 $\mu \mathrm{g} / \mathrm{m}^{3}$, as well as the $\mathrm{Pb}$ contained in the rain water runoff (fall on ground surface) on urban region is higher than rural region with $400 \mu \mathrm{g} / \mathrm{l}$ compare to $80 \mu \mathrm{g} / \mathrm{l}$.

Some lead $(\mathrm{Pb})$ source from rain water reservoired after flow through rooftop are dust particle in the air which contain lead that can sediment on urban rooftop. It can also come from automotive and industrial emition (Sudarmadji, 2014). Other sources are dust from burned rice field and plantation and material of the rooftop used to flow the rain water.

Land burning from rice field or plantation where the land structure in Pontianak and Kubu Raya District is consist of peat will produce dust particle containing $\mathrm{Pb}$, so when the rain fall it will increase $\mathrm{Pb}$ element flowing on rooftop. The research found out that $\mathrm{Pb}$ contained in rain water directly reservoired (does not flow through rooftop) the lead level is $0,1097 \mathrm{mg} / \mathrm{l}(109,7) \mu \mathrm{g} / \mathrm{l}$ and contained in rain water flowing through zinc rooftop is 0,1317 $\mathrm{mg} / \mathrm{l}(131,7 \mu \mathrm{g} / \mathrm{l})$. It can be seen that the last one has higher $\mathrm{Pb}$ level and insufficient to drinking water qualification as regulated in Ministry of Health Regulation number 492/2010 and WHO (2011) about Guidelines for Drinking Water Quality.

Meanwhile result of $\mathrm{Pb}$ test on rain water directly reservoired and not flowing through zinc rooftop in Pontianak is 211,65 $\mu \mathrm{g} / \mathrm{l}$, which is higher than sub urban or rural region District Kubu Raya with $51,75 \mu \mathrm{g} / \mathrm{l}$. This result showing that side effect of fuel combustion using $\mathrm{Pb}$ as octane booster is affecting $\mathrm{Pb}$ pollution in rain water. The height of pollution on urban region increase rain water turbidity. It is higher in urban region (Pontianak) than rural region
(Kubu Raya) with 21.92 NTU compare to 18.08 NTU. As for $\mathrm{pH}$ level, for urban region is lower with $\mathrm{pH} 4.78$ compare to sub urban or rural region with $\mathrm{pH} 5.54$.

The height of $\mathrm{Pb}$ on rain water beside affected by air dust particle condition resulted from land and fuel burning, can also comes from material used for collecting and conserving rain water. It can be known from test result on $\mathrm{Pb}$ contained in rain water, comparing directly reservoired and flowing through zinc rooftop. The one that flows through zinc rooftop has higher $\mathrm{Pb}$ containtment with $131.7 \mu \mathrm{g} / \mathrm{l}$ compare to $109,7 \mu \mathrm{g} / \mathrm{l}$ for directly reservoired. This is caused by acid properties of rain water and ambient humidity that trigger corrotion on zinc rooftop. The $\mathrm{Pb}$ as bonded agent of fero and zinc is dissolved in rain water.

It also influenced by nature of Pontianak and Kuburaya which is located on tropical region and precisely located on the equator, thus both region is exposed to sun shine for whole year and rain for whole day, particularly on October and March.

As so, the pollutan from land burning and fuel combustion produce tetra ethyl lead and tetra methyl lead. Both material will be unravelled and become mono ethyl- $\mathrm{Pb}$, diethyl- $\mathrm{Pb}$ and triethyl- $\mathrm{Pb}$. All organical $\mathrm{Pb}$ has properties of easily dissolved in water (Palar, 2012). The $\mathrm{Pb}$ dissolving in rainwater, beside related with sun, humidiy, kind of $\mathrm{Pb}$, also influenced by acid and alkali properties of rain water. Generally, rain water has soft properties with high acid $(\mathrm{pH}<5)$. In this condition, $\mathrm{Pb}$ is easily dissolved in rain water and flows along to the reservoir and unqualified to be consumed.

Research result indicates that acidity of rain water in Pontianak is pH 4.78 and Kubu Raya $\mathrm{pH}$ 5.54. This values is cathegorized as high $\mathrm{pH}$. With average $\mathrm{pH} 5.16$, it is higher than Malang with pH 7.4 (Untari, 2015) and in Misurata Libya with pH 7.87 - 8.54. High acidity will increase solubility and toxidity of heavy metal material like $\mathrm{Pb}$. As so, it will cause health disorder to the community using it as drinking water. Examination on $\mathrm{Pb}$ exposure level to community's health is conducted by urine test (Mulyadi, 2015). Pb exposure in blood has relation with Haemoglobin and Cystasin, though $\mathrm{Pb}$ does not contribute to digestion 
disorder and central nerve system. The increase of lead level in blood can also trigger anti-social in work environtment (marianti, 2015).

Beside $\mathrm{Pb}$ contained and rain water $\mathrm{pH}$, turbidity of rain water in Pontianak and Kubu Raya as drinking water source is cathegorized as high. From the research result, average turbidity of rain water in Pontianak is 21,92 NTU and Kubu Raya 17,84 NTU. This result is above value mentioned in Ministry of Health Regulation number 492 year 2010 about requirement of drinking water quallity and WHO standard (2011) Guidelines for Drinking Water Quality which is 5 NTU. This result is higher than other place, like turbidity of rain water on Embakasi, Nairobi, with 2.9 NTU (Gakungu, 2013) and Malang, East Java with 1.05 NTU (Untari, 2015).

Generally, turbidity in water caused by suspended solid substance, either organic or unorganic (Soemirat, 2011). High turbidity indicate that rain water is polluted physically, chemically and biologically. Physical pollution like animal waste (bird), dust from rice field and plantation burning. Chemical pollution like fuel combustion from automotive and industrial burning, including chemical material of zinc rooftop used to trap and reservoir rain water. While microbiologically come from virus and bacteria in the air. All those make high turbidity of the rain water and not feasible to be consumed.

Beside lead $(\mathrm{Pb})$ contained and turbidity of rain water, it can be seen that average $\mathrm{pH}$ value is low with 5.02. $\mathrm{pH}$ in Pontianak is $\mathrm{pH}$ 4.78 which is lower than sub urban region and rural like Kubu Raya with $\mathrm{pH}$ 5.26. The value is still below of drinking water requirement standar as arranged by Ministry of Health Regulation number 492 year 2010 and WHO standard (2011) regarding Guidelines for
Drinking Water Quality which the $\mathrm{pH}$ should be $6.5-8.5$. Drinking water source including rain water can be consumed if the $\mathrm{pH}$ is $6.5-$ 8.5. Low $\mathrm{pH}$ is related with water process, it has corrosive properties and interferes disinfection process (WHO, 2011). On soft water like rain water with $\mathrm{pH}$ less than 5 will cause high solubity of metal, particularly lead $(\mathrm{Pb})$. The $\mathrm{Pb}$ comes from piping system or other metal material, like the rooftop used to capture and reservoired rain water. It will be rusty and dissolved in rain water. Thus the low $\mathrm{pH}$ of rain water $(\mathrm{pH}<5)$ has relation with high solubity of toxic metal, like $\mathrm{Pb}$, and it will not feasible to be consumed.

As been identified that rain water in Pontianak and Kubu Raya contain high $\mathrm{Pb}$, high turbidity and low $\mathrm{pH}$, outline of threshold either refers to Ministry of Health Regulation number 492 year 2010 nor WHO standard (2011) regarding Guidelines for Drinking Water Quality, as much as $0,01 \mathrm{mg} / \mathrm{l}(10 \mu \mathrm{g} / \mathrm{l})$. Therefore, to decrease the $\mathrm{Pb}$ contained and turbidity and increase the $\mathrm{pH}$ to $6.5-8.4$, a process by appropriate technology is required.

Rain water process with appropriate technology has some benefit like affordable, local materials usage and convenient built. So community will interesting to apply it, particularly for rain water process with result of standard quality drinking water.

From the table can be seen that rain water turbidity flowing through zinc rooftop before processed by shell sand and activated carbon filtration system in the filter tube, maximum turbidity is $26.81 \mathrm{NTU}$ and lowest at 15.06 NTU with average value 20 NTU. After processed it become $14.96 \mathrm{NTU}$ for highest value and $0.14 \mathrm{NTU}$ at the lowest with average value 5.67 NTU. Statistical tes indicates that there is significant difference of rain water

Table 5. Difference of Rain Water Turbidity Before and After Process

\begin{tabular}{lllll}
\hline & $\mathrm{N}$ & $\begin{array}{l}\text { Median } \\
\text { (Minimum-Maximum) }\end{array}$ & Average \pm s.b & $\mathrm{P}$ \\
\hline $\begin{array}{l}\text { Turbidity Before } \\
\text { Process }\end{array}$ & 40 & $18,95(15,06-26,81)$ & $20,0025 \pm 3,33$ & \\
$\begin{array}{l}\text { Turbidity After } \\
\text { Process }\end{array}$ & 40 & $2,92(0,14-14,96)$ & $5,67 \pm 5,15$ & 0,00 \\
\hline
\end{tabular}

Source: Primary Data 
Table 6. Difference of Rain Water pH Before and After Process

\begin{tabular}{llcccc}
\hline & $\mathrm{N}$ & Average \pm s.b & $\begin{array}{c}\text { Average difference } \\
\pm \text { s.b }\end{array}$ & IK95\% & P \\
\cline { 1 - 2 } pH Before Process & 40 & $5,33 \pm 0,52$ & \multirow{2}{*}{$1.78625 \pm 0,55$} & $1,61-1,96$ & 0,000 \\
\cline { 1 - 4 } pH After Process & 40 & $7,01 \pm 0,21$ & &
\end{tabular}

Source:Primary Data

turbidity before and after processed by shell sand and carbon activated absorbtion in the filter tube, with $\mathrm{p}$ value 0.000 .

From above table can be seen that rain water flowing through zinc rooftop before process has average $\mathrm{pH} 5.16$ and after process become 6.95 . The effectivity of the process with shell sand filtration techique and activated carbon absorbtion, the lowest is $18 \%$, the highest is $34 \%$ and the average is $26 \%$. Result of statistic test indicates that there is significant difference between $\mathrm{pH}$ of rain water flowing through zinc rooftop before and after process with shell sand filtration and activated carbon in filter tube with $\mathrm{p}$ value 0.000 .

To decrease $\mathrm{Pb}$ contained in the water, particularly rain water can be done by several methods, like arrangement of reservoired time and process with shell sand filtration and activated carbon technique. The technique is commonly used for surface water and land water having high metal containt, like $\mathrm{Fe}, \mathrm{Hg}$ and $\mathrm{Pb}$. The technique to reduce pollutant contained in rain water is by using filter tube with gravel, shell sand and activated carbon made of coconut shell media.

Research result indicates that the usage of shell sand filtration and activated carbon absorbtion made of coconut shell is very effective to reduce $\mathrm{Pb}$ and turbidity and could increase $\mathrm{pH}$ of rain water. The effectivity in $\mathrm{Pb}$ reduction is $99.47 \%$, turbidity reduction is $72 \%$ and $\mathrm{pH}$ increase is $35 \%$. The result of statistical analysis descript that it is highly significant in reducing $\mathrm{Pb}(\mathrm{p}=0,001)$, turbidity $(\mathrm{p}=0,000)$ and increase $\mathrm{pH}(\mathrm{p}=0.000)$

Research result indicates that the process to reduce $\mathrm{Pb}$ contained in rain water with shell sand filtration techique and activated carbon absorbtion has high effectivity with $99.47 \%$. With average $\mathrm{Pb}$ before process is $0,1317 \mathrm{mg} / \mathrm{l}$ $(131,7 \mu \mathrm{g} / \mathrm{l})$ and after process is $0,00069 \mathrm{mg} / \mathrm{l}$ $(0,69 \mu \mathrm{g} / \mathrm{l})$. Statistical analysis resulting that the
$\mathrm{Pb}$ contained in rain water significantly smaller than before process $(\mathrm{p}=0.001)$, reduce turbidity $(\mathrm{p}=0.00)$ and increase $\mathrm{pH}(0.00)$.

Similar study by Eppeda (2012), the usage of filter with media sand, made of palm shell - carbon and gravel is effective to reduce turbidity, appearance and increase $\mathrm{pH}$ of surface water (Pinoh River) on District Melawi, West Kalimantan. Before process, appearance is 226 Pt.Co, turbidity is $47 \mathrm{NTU}$ and $\mathrm{pH}$ 7.12. After process, appearance is $6.0 \mathrm{Pt}$.Co, turbidity is 2.0 NTU and $\mathrm{pH}$ increase $4.78 \%$. Other study by Untari (2015) obtained result that usage of filter with media sand, activated carbon absorbtion, zeolite and gravel can reduce turbidity from $1.05 \mathrm{NTU}$ to $1.02 \mathrm{NTU}$.

The reduction of $\mathrm{Pb}$ contained, turbidity level and $\mathrm{pH}$ increase could be started after the substance contained by rain water flows through filter tube with made of coconut shell activated carbon granule, shell sand and gravel media. Length of filter tube should be $120 \mathrm{~cm}$ with thickness of gravel media $10 \mathrm{~cm}$, sand shell media $20 \mathrm{~cm}$ and activated carbon granule 10 $\mathrm{cm}$. Function of sand filtration media generally and shell sand filtration media particulary is to filtrate and decrease turbidity level. The turbidity of rain water come from dust particles including $\mathrm{Pb}$, bird waste and microorganism or usually based on pollutan characteristic on one region or city. Shell sand filtration media in filter tube when used will form a film layer effectively functioned to filtrate pollutant particles like metal dust or others non metal dust such as bacteria, virus and appearance of rain water.

The effectivity of shell sand filter is higher to reduce $\mathrm{Pb}$ particle and turbidity and increase $\mathrm{pH}$ on rain water compare to usual sand (quartz) and activated carbon used for filtration, like the process with quartz sand filtration media on river water process resulting $4.7 \% \mathrm{pH}$ increase and rain water 2.9\% (Eppeda, 
2012; Untari, 2015) while shell sand could increase rain water $\mathrm{pH}$ up to $26 \%$. This better ability is due to it is taken from the beach which rich of calcium oxide $(\mathrm{CaO})$ or chalk. Beside, shell sand also has ability to absorb heavy metal contained in the water and bond suspended materials.

Rain water is not always a good source of ready to drink-clean water, physicaly colorless, tasteless and clear. Rain water is highly influenced by the region where the rain water falling (Soemirat, 2011). On rural region, rain water could be polluted by impurities from land burning, pestiside and animal waste. While on urban region, it can be polluted by tasteless, colorless, unvisible suspended chemicals. Such as $\mathrm{Pb}$ comes from rooftop and paint, zinc, tar, dust and asbestos. Beside, it could also comes from vulcano eruption, fuel combustion of automotive emition and industrial activity (Sudarmadji, 2014).

With so many possible impurities, could increase the turbidity of the rain water. Water turbidity, particularly rain water could also come from suspended solid suspense, wheter organic or unorganic, biological source like bacterial, virus and parasite having air bourne properties-pollutant (Soemirat, 2011).

To reduce or decrease the air borne pollutant contained in rain water, a process is conducted by shell sand filtration technique and made of coconut shell-activated carbon absorbtion. The fundamental of rain water filtration is by flows rain water through some kind of porous media towards particle substance that can't be separated by sedimentation process. On rain water process, the pollutant escape from filtration stage will going through absorbtion process. The method of shell sand filtration process and activated carbon absorbtion is proven that it can reduce turbidity of rain water from 20 NTU to 5.67 NTU (72\% effectivity) and convert it to standard drinking water

On rain water process with absorbtion, beside to carry on decreasing of suspended organic and unorganic substance escape from filtration process, also to reduce metal substance in the rain water, such as lead $(\mathrm{Pb})$. The $\mathrm{Pb}$ contained in rain water does not meet the drinking water standard and therefore is not feasible to be consumed. The result of this study obtain that $\mathrm{Pb}$ contained in rain water does not meet the drinking water standard, with average $\mathrm{Pb}$ before process is $131,7 \mu \mathrm{g} / \mathrm{l}$. After being processed it become $0,69 \mu \mathrm{g} / \mathrm{l}$ (effectivity 99.47\%)

The ability of activated carbon to absorb $\mathrm{Pb}$ contained in rain water is due to it has microporous and mesoporous volume that relatively large as so, it also has wide surface. The condition increases possibility to absorb the particles (include $\mathrm{Pb}$ metal) in sufficient amount. Activated carbon is one kind of absorber whose amorphous carbon structures, most of them are free carbon and have deep inner surface, thus has well absorbility to reduce lead $(\mathrm{Pb})$ contained in rain water and turbidity while it also increase the $\mathrm{pH}$ number. The parameters then be converted so that sufficient to drinking water quality standard in Ministry of Health Regulation number 492/2010 and WHO standard (2011) about Guidlines for Drinking Water Quality, which for $\mathrm{Pb}$ level should be less than $10 \mu \mathrm{g} / \mathrm{l}$, turbidity 5 NTU and $\mathrm{pH}$ between $6.5-8.5$.

\section{Conclusion}

Referenced to the results, then can be concluded that : (1) lead $(\mathrm{Pb})$ contained in rain water and turbidity before process is high with $\mathrm{Pb} 131,7 \mu \mathrm{g} / \mathrm{l}$ and turbidity 20 NTU. After processed by using shell sand filtration and made of coconut shell - activated carbon absorbtion, it become $0,71 \mu \mathrm{g} / \mathrm{l}$ for lead contained dan turbidity 5,66 NTU. This condition is sufficient to drinking water quality standard in Ministry of Health Regulation number 492/2010 and WHO standard (2011) about Guidlines for Drinking Water Quality. (2) The process of rain water by using shell sand filtration and made of coconut shell - activated carbon absorbtion is highly effective to decrease lead $(\mathrm{Pb})$ contained in rain water and the turbidity, with effectivity $99.47 \%$ and $71.65 \%$. Statistical analysis indicates that $\mathrm{Pb}$ and turbidity of rain water after the process is lower than before process $(\mathrm{p}=0.000)$.

Therefore, for community of Pontianak and Kubu Raya, is advised to apply this process before using rain water as drinking water source, particularly for houses using zinc rooftop, since the $\mathrm{Pb}$ contained and the turbidity is above the required threshold. It is advised that the process 
is conducted simply by using local materials available in the region conform to the ability without eliminating concept of $\mathrm{Pb}$ and turbidity reduction on rain water used, like conducting rain water process by using shell sand filtration and made of coconut shell - activated carbon absorbtion in filter tube. As for Community Health Care Centre and Public Health Office could provide the facility to simply process the rain water or coaching program to empower the community in managing rain water as drinking water source

\section{References}

Adha, A. N, Asmadi, Anwar, T. 2015. Hubungan Kualitas Bakteriologis Air Sumur Gali (SGL) Dengan Kejadian Diare Pada Anak Balita di Desa Seluas Kec. Seluas Bengkayang Kalbar. Jurnal Kesehatan, Sanitarian, 7(1): 39-46

BMKG. 2014. Pengamatan Data Curah Hujan 2014. Pontianak Kalbar.

Dinkes Kab. Kubu Raya. 2014. Profil Kesehatan Kab. Kubu Raya 2013. Dinkes Kab. Kubu Ray

Dinkes Kota Pontianak. 2014. Profil Dinas Kesehatan Kota Pontianak Tahun 2013. Dinkes Kota Pontianak.

Dinkes Prop. Kalbar. 2014. Profil Kesehatan Kalimantan Barat 2013. Dinkes Propinsi Kalbar, Pontinak.

Eppeda, Fathmawati. 2012. Pengolahan Air Sungai Menggunakan Filter Pasir dan Arang Batok Kelapa Sawit. Jurnal Kesehatan Sanitarian, 4 (2): halaman 2087 - 6394.

Fardiaz, S. 2012. Polusi Air dan Udara. Penerbit Kanisius. Yogyakarta, Cet. 11.

Gakungu, J. N. 2013. Qualitative Assessment of Rain Water Harvested from Roof Top Catchments: Case Study of Embakasi, Nairobbi Country. International Journal of Soft Computing and Engineering (IJSCE), $3: 263-266$

Kemenkes. 2001. Bahan-bahan Berbahaya dan Dampaknya terhadap Kesehatan Manusia (sebagai Referensi dalam Melaksanakan
$A D K L)$. Dirjen PPM \& PLP Dekpes RI, Jakarta.

Kemenkes. 2010. Peraturan Menteri Kesehatan, No. 492/Menkes/Per/IV. 2010. Tentang Persyaratan Kualitas Air Minum. Kemenkes RI, Jakarta.

Kemenkes. 2014. Profil Kesehatan Indonesia Tahun 2013. Sekretariat Jenderal dan Pusdatin Kemenkes RI, Jakarta.

Marianti, A, Anies, A, \& Abdurachim, H. R. S. 2015. Peningkatan Kadar Timbal Darah dan Munculnya Perilaku Antisosial Pengrajin Kuningan. Jurnal Kesehatan Masyarakat, 11(1): 144-154.

Mayouf, J.A. Determination of Iron, Copper, Lead and Cadmium Concen-tration in Rain Water Tanks in Misurata. Libya, International Journal of Physical Sciences, 2 (5) : 112-118.

Muliyadi, M. 2015. Paparan Timbal Udara terhadap Timbal Darah, Hemoglobin, Cystatin C Serum Pekerja Pengecatan Mobil. Jurnal Kesehatan Masyarakat, 11(1) : 87-95.

Palar, H. 2012. Pencemaran dan Toksikologi Logam Berat. Penerbit Rineka Cipta, Jakarta, Cetakan ke-4.

Sastrawijaya, A.T. 2009. Pencemaran Lingkungan. Penerbit Rineka Cipta. Jakarta, Cetakan ke-2.

Soemirat, Y. 2011. Kesehatan Lingkungan. Gadjah Mada University Press. Yogyakarta, Cetakan ke-8 (Edisi Revisi).

Sudarmadji. 2014. Potret Masalah Lingkungan Sekitar Jalan Perkotaan. Penerbit Depublish (Grup Penerbitan CV Budi Utama), Sleman, Yogyakarta.

Untari, T., Kusnadi, J. (2015). Pemanfaatan Air Hujan Sebagai Air Layak Konsumsi Di Kota Malang Dengan Metode Modifikasi Filtrasi Sederhana. Jurnal Pangan dan Agroindustri, 3(4) : 1492-1502

WHO. 2011. Guidelines for Drinking Water Quality. WHO, Geneva, Switzerland, 4 thed.

Widiyanto, A. F, Yuniarno, S, \& Kuswanto, K. 2015. Polusi Air Tanah Akibat Limbah Industri dan Limbah Rumah Tangga. Jurnal Kesehatan Masyarakat, 10 (2): 246-254. 